\title{
Post-traumatic Tension Pneumoventricle: Case Report
}

\section{Pneumoventrículo hipertensivo pós-traumático: relato de caso}

\author{
Ricardo Macedo Camelo ${ }^{1}$ Josias Inácio da Silva ${ }^{1}$ Rafael Costa Camelo ${ }^{1}$ Moana Vergetti Malta ${ }^{2}$ \\ Arnon Castro Alves Filho ${ }^{2}$ Washington Clésio da Silva Ribeiro ${ }^{2}$ Adans Soares Porfírio ${ }^{2}$ \\ Daniel Fonseca Oliveira ${ }^{2}$
}

${ }^{1}$ Department of Neurosurgery, Medical Residency Program, Hospital

Universitário Professor Alberto Antunes, Maceió, AL, Brazil

2 Department of Neurosurgery, HUPAA, Maceió, AL, Brazil

Address for correspondence Moana Vergetti Malta, MD, Serviço de Neurocirurgia do Hospital Universitário Professor Alberto Antunes, Av. Lourival Melo Mota, s/n, Cidade Universitária, Maceió, AL, Brazil

Arq Bras Neurocir 2018;37:275-279.

57072-900 (e-mail: moana_malta@hotmail.com).

\begin{abstract}
Keywords

- pneumoventricle

- liquoric fistula

- cranioencephalic trauma

Resumo

Palavras-Chave

- pneumoventrículo

- fístula liquórica

- traumatismo cranioencefálico

Pneumoventricle and liquoric fistula are possible complications of traumatic brain injury (TBI), the main cause of morbimortality related to trauma in Brazil. Liquoric fistulae are more common after direct trauma with skull base fractures. However, pneumoventricle is rare and occurs due to excessive cerebrospinal fluid (CSF) drainage in the presence of a poorly compliant ventricle system, resulting in the influx of air to its interior. The pathophysiology of tension pneumoventricle remains uncertain. However, the traumatic cause is certain and multiple bone fractures of the face and liquoric fistula may contribute to the process. If symptomatic, the tension pneumoventricle can cause rapid clinical deterioration. The authors aim to report a rare case of post-TBI tension pneumoventricle with complete resolution and without signs of recurrence of the liquoric fistula after surgical treatment.

O pneumoventrículo e a fístula liquórica são possíveis complicações decorrentes do traumatismo cranioencefálico (TCE), principal causa de morbimortalidade relacionada ao trauma no Brasil. As fístulas liquóricas são mais comuns após traumas diretos, com fraturas da base do crânio. Já o pneumoventrículo é raro e ocorre após a drenagem liquórica excessiva, na presença de sistema ventricular pouco complacente, resultando em um influxo de ar para o seu interior. A fisiopatologia do pneumoventrículo hipertensivo permanece incerta. Entretanto, a causa traumática é certa, e múltiplas fraturas de ossos da face e a fístula liquórica podem ter contribuição no processo. Se for sintomático, o pneumoventrículo hipertensivo pode provocar rápida deterioração clínica. Os autores têm por objetivo relatar um caso raro de pneumoventrículo hipertensivo após TCE com completa resolução e sem sinais de recorrência da fístula liquórica após tratamento cirúrgico.
\end{abstract}

received

September 29, 2015

accepted

January 11, 2016

published online

April 14, 2016
DOI https://doi.org/

10.1055/s-0036-1581996. ISSN 0103-5355.
Copyright $(2018$ by Thieme Revinter

Publicações Ltda, Rio de Janeiro, Brazil
License terms

(요 (1) $\Theta$ 


\section{Introduction}

Pneumoventricular and liquoric fistulae are possible complications of traumatic brain injury (TBI), the main cause of trauma-related morbimortality in Brazil. ${ }^{1}$ Liquoric fistulae are more common after direct trauma, with fractures of the base of the skull. ${ }^{1-4}$ Pneumoventricle is rare and occurs after excessive cerebrospinal fluid (CSF) drainage, in the presence of a poorly compliant ventricular system, resulting in the influx of air into its interior. The pathophysiology of the tension pneumoventricle remains uncertain. However, the traumatic cause is certain, and multiple facial bone fractures and liquoric fistulae may contribute to the process. ${ }^{1}$ If it is symptomatic, the tension pneumoventricle can lead to rapid clinical deterioration. ${ }^{1,2,5-7}$ The authors aim to report a rare case of tension pneumoventricle after TBI.

\section{Case Report}

A 43-year-old male patient with a history of TBI due to an automobile accident on March 18th, 2012, was treated at an emergency unit and was discharged after 8 days. He returned to the service 6 days later with headache and rhinoliquorrhea. A computed tomography (CT) exam of the skull showed pneumocephalus and right ethmoid fracture. The patient received clinical medical treatment, without resolution of the liquoric fistula and was then transferred to a reference hospital for definitive neurosurgical treatment. The condition of the patient evolved with vomiting, and a new CT scan of the skull (-Figs. 1-2) was performed, evidencing the presence of a hypertensive pneumoventricle. The patient was then submitted to an external ventricular shunt placement and a bifrontal craniotomy, using pericranium and biological glue on the floor of the anterior cranial fossa for correction of the liquoric fistula and of the pneumoventricle. Postoperatively, he evolved satisfactorily, with resolution of the pneumoventricle (-Figs. 3-4) and no signs of recurrence of the fistula.

\section{Discussion}

Pneumocephalus is the presence of air in any intracranial compartment through a connection between the central nervous system (CNS) and the environment. ${ }^{5}$ It is called a pneumoventricle when the air is in the intraventricular space. Pneumocephalus, despite having a common incidence, have a rare intraventricular presentation and, if symptomatic, may cause rapid clinical deterioration. ${ }^{1,4-8}$

The presence of a liquoric fistula implies the existence of a dural and bone opening that establishes a communication between the subarachnoid space and the contaminated cavities of the upper airways, and its cause can be traumatic or non-traumatic. Among the non-traumatic causes are elective craniotomies. ${ }^{5}$ The pneumoventricle is a common postoperative event, especially in posterior fossa or transventricular approaches, particularly in patients operated in the seated position. ${ }^{5,7}$ The case reported in the present study had a traumatic cause, and this is the most frequently found in the literature. $^{1}$

The majority of the patients with pneumocephalus remains asymptomatic and requires no intervention, with spontaneous resorption. In some cases, however, air collection may cause increased intracranial pressure, with neurological deterioration. The clinical presentation of tension pneumocephalus may include headache, seizures, decreased level of consciousness, nausea, vomiting, dizziness, focal deficits, and even coma, consequent to the intracranial hypertension. ${ }^{1,4-9}$ The time of

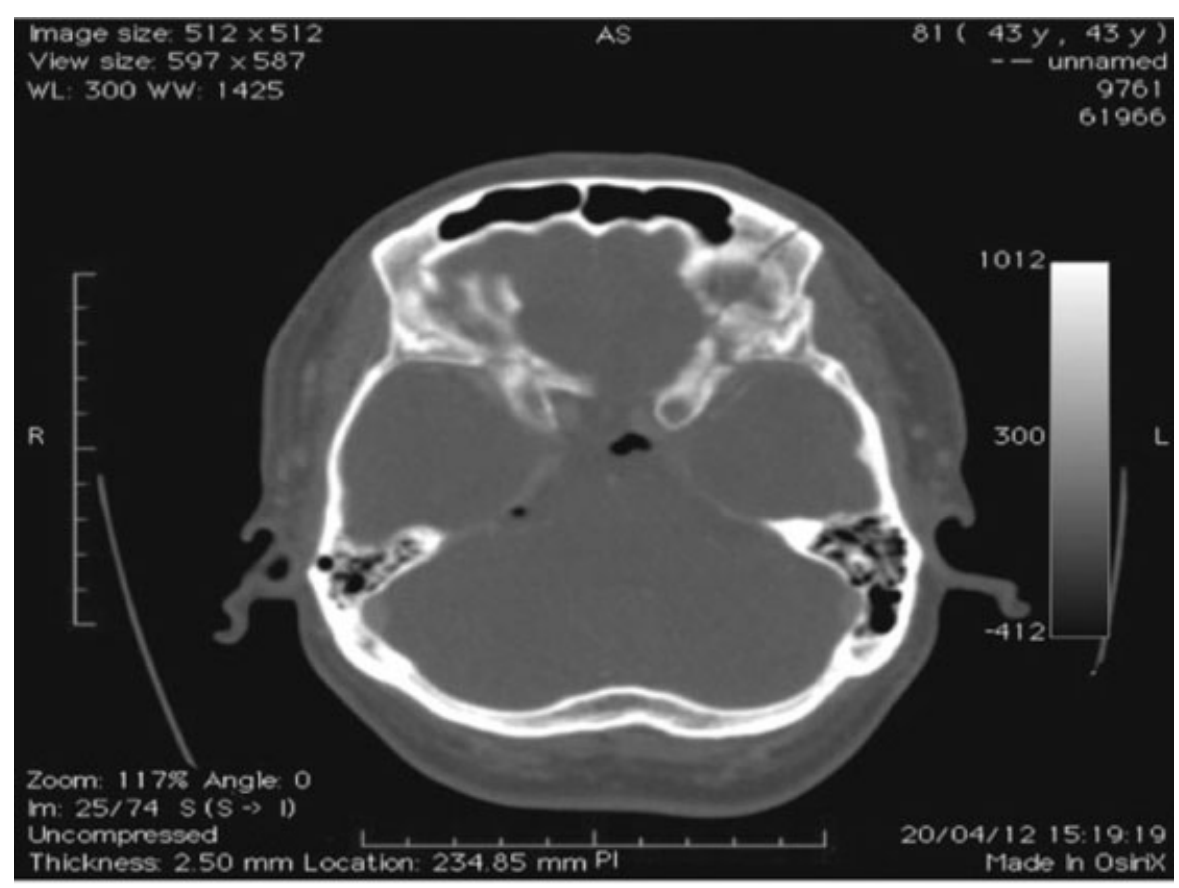

Fig. 1 Preoperative computed tomography showing skull base fracture. 


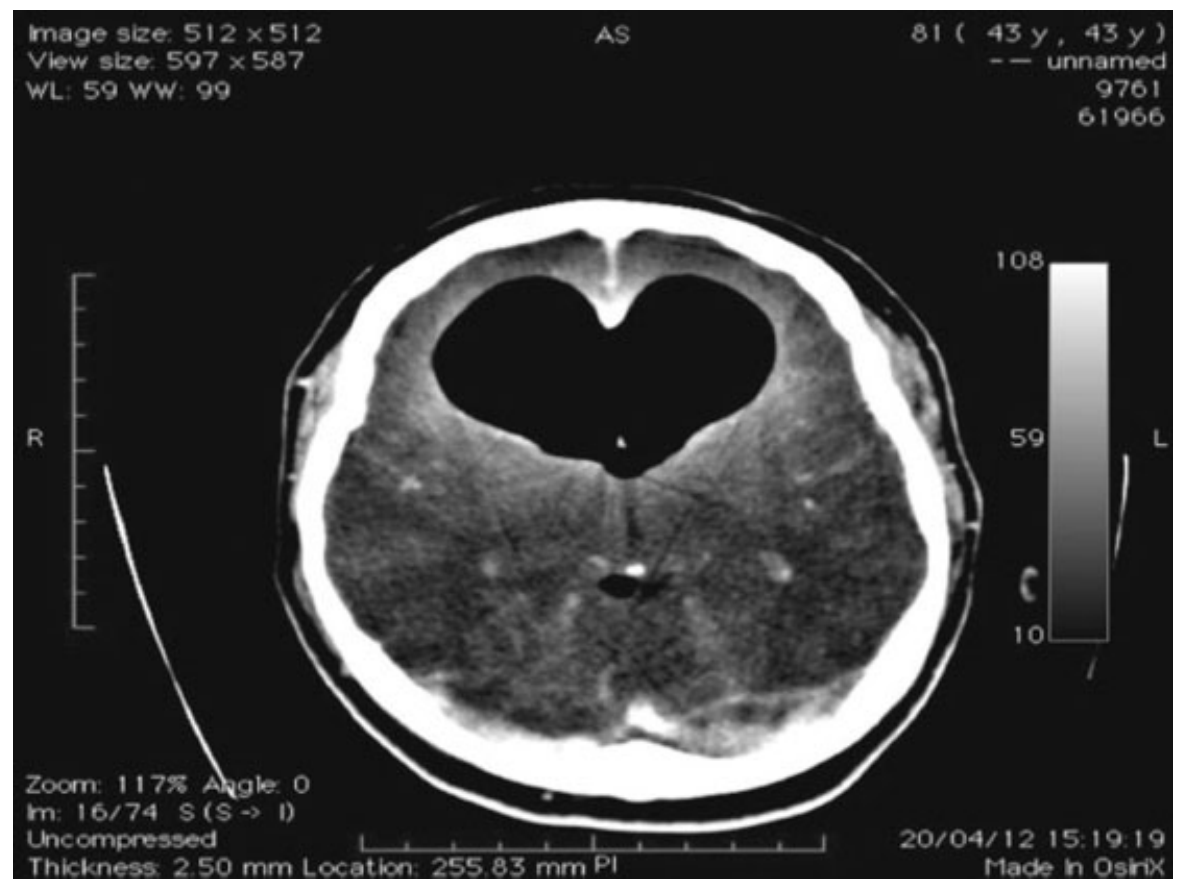

Fig. 2 Preoperative computed tomography showing bulky tension pneumoventricle.

onset of symptoms is variable. The patient in the present case presented with headache and vomiting, which began 14 days after the trauma.

The diagnosis can be made by a simple skull radiography, but $\mathrm{CT}$ is the gold standard. ${ }^{1,2,4-6,9,10}$ It is a sensitive examination in the detection of air even in small volumes $(<0.5$ $\mathrm{mL})^{2,4,7,10}$ The presence of porencephalic cysts may indicate the fistulation point, since the cyst tends to be located below the fistula. The treatment of pneumocephalus may be conser- vative, by lumbar shunt, or surgical exploration with intra or extracranial access. ${ }^{1,9}$ The conservative treatment, often effective, includes oxygen therapy (through the use of $100 \%$ oxygen chambers or hyperbaric oxygenation), antibiotic therapy (of controversial use ${ }^{2}$ ), analgesia, neurological exams and serial CT for the evaluation of the evolution of the patient.

Hyperbaric oxygen therapy was recognized in 1995 by the Federal Council of Medicine (CFM, in the Portuguese acronym) as a therapeutic modality through resolution No. 1457/

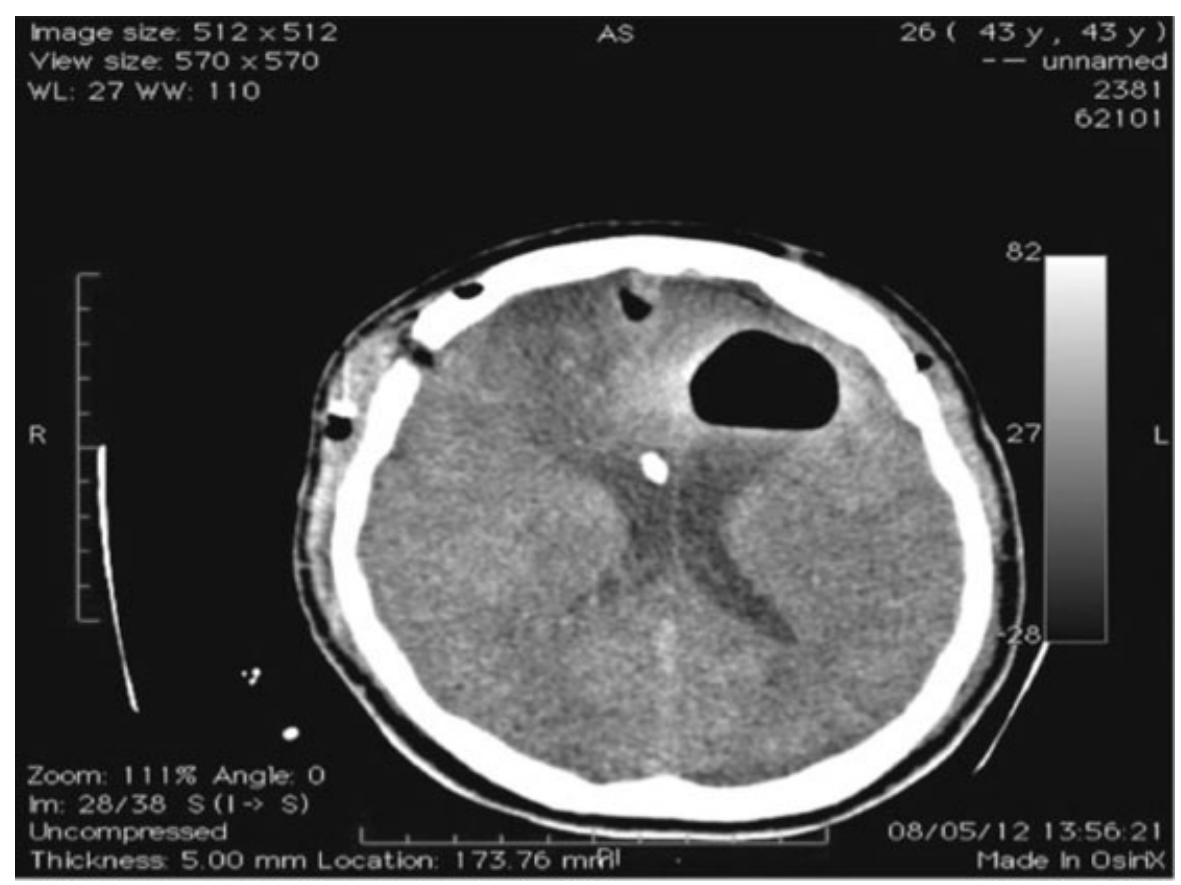

Fig. 3 Postoperative computed tomography showing resolution of the pneumoventricle. 


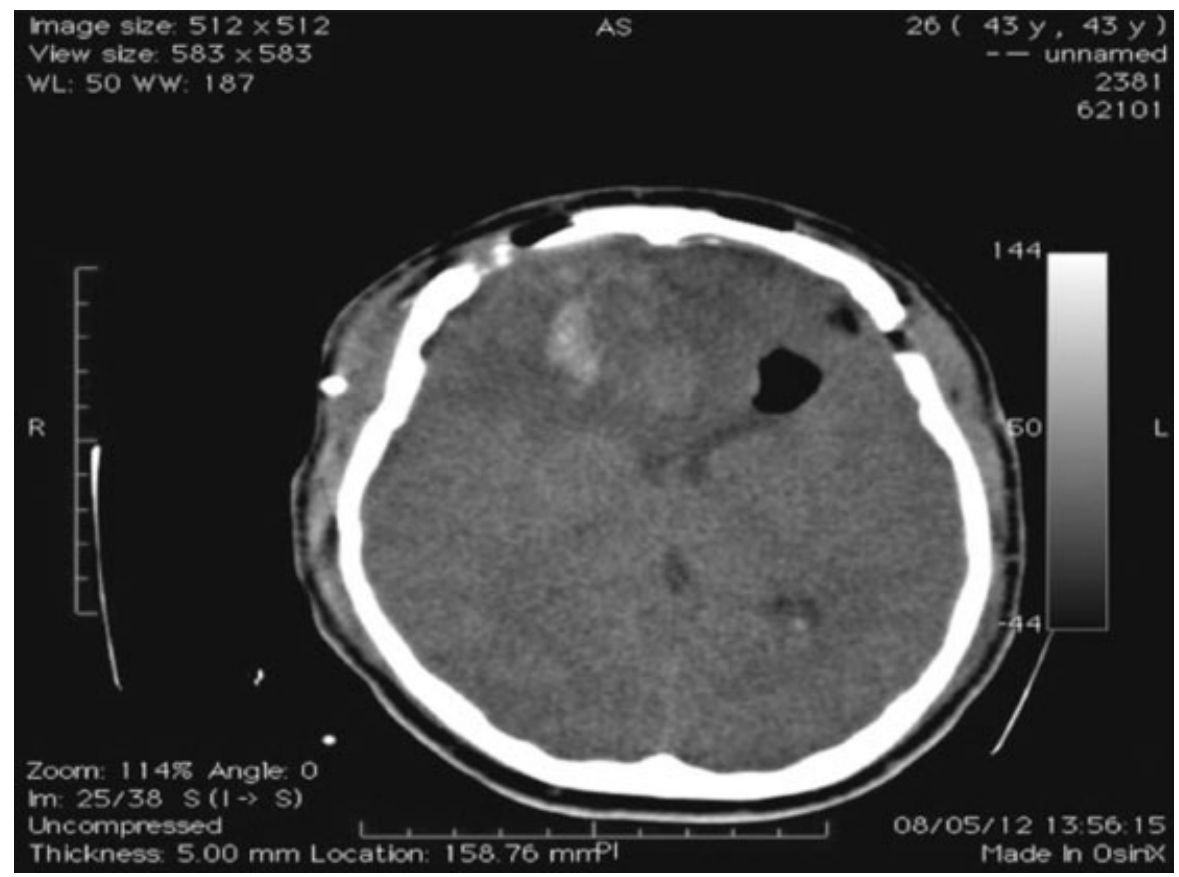

Fig. 4 Postoperative computed tomography showing resolution of the pneumoventricle.

95, and it was subsequently recognized by the Brazilian Medical Association (AMB, in the Portuguese acronym). Indications for the method are based on clinical studies and indications developed by the International Committee on Hyperbaric Oxygen Therapy, which establishes institutions around the world, such as the Undersea and Hyperbaric Medical Society and the European Committee on Hyperbaric Medicine. In pneumocephalus, oxygen therapy works because oxygen replaces the nitrogen component, which is more rapidly absorbed into the bloodstream (Graham law), and thus stabilizes the condition within 48 hours. ${ }^{11}$ In the case of hyperbaric oxygen therapy, there is an acceleration of the pneumocephalus reabsorption process in symptomatic patients or in patients with persistent pneumocephalus after $100 \%$ oxygen normobaric therapy. ${ }^{11}$

Unlike pneumocephalus, the occurrence of hypertensive pneumoventricles is rare and occurs, in most reported cases, after procedures for the placement of cerebrospinal fluid shunts in patients with hydrocephalus. ${ }^{5,7}$ It is a neurosurgical emergency that usually requires an invasive approach. ${ }^{1,4-6,9,10}$ Many authors believe that the treatment should be focused on the surgical closure of the airway. ${ }^{2}$ In the patient in question, there was no resolution of the liquoric fistula through conservative treatment; on the contrary, the patient developed a worsening of the condition with signs of intracranial hypertension, and surgical treatment was performed by means of bifrontal craniotomy and external ventricular derivation.

The external ventricular derivation in these cases is fundamental, since it provides the output of the hypertensive air. A physiological solution is introduced via a catheter into the ventricular system, occupying the place of the hypertensive air that goes out into the environment. ${ }^{7}$ It is important to note that, in this case, there is a somewhat less invasive alternative: the introduction of a physiological solution through a ventricular catheter, concomitant with the attempt to correct the basal fistula by means of an endoscopic procedure at the base of the skull, sparing the patient of bifrontal craniotomy. However, this alternative is only feasible in services where there is experience with the endoscopic technique.

\section{Conclusion}

Although rare, the tension pneumoventricle should be considered in patients with post-traumatic liquoric fistula, especially when there is neurological deterioration, since it is a neurosurgical emergency requiring an invasive approach in most cases.

\section{References}

1 Carmona KC, Fantine JSE, Vieira CN, et al. Pneumoventrículo hipertensivo pós-traumático: relato de caso. Rev Med Minas Gerais 2010;20(2, Suppl 1)129-132

2 Tuğcu B, Tanriverdi O, Günaldi O, Baydin S, Postalci LS, Akdemir H. Delayed intraventricular tension pneumocephalus due to scalpventricle fistula: a very rare complication of shunt surgery. Turk Neurosurg 2009;19(03):276-280

3 Kanner AA, Nageris BI, Chaimoff M, Rappaport ZH. Spontaneous pneumocephalus in the posterior fossa in a patient with a ventriculoperitoneal shunt: case report. Neurosurgery 2000;46 (04):1002-1004

4 Simmons J, Luks AM. Tension pneumocephalus: an uncommon cause of altered mental status. J Emerg Med 2013;44(02):340-343

5 Radhziah S, Lee CK, Ng I. Tension pneumoventricle. J Clin Neurosci 2006;13(08):881-883 
6 Kuo MY, Lien WC, Wang HP, Chen WJ. Nontraumatic tension pneumocephalus-a differential diagnosis of headache at the ED. Am J Emerg Med 2005;23(02):235-236

7 Gupta N, Rath GP, Mahajan C, Dube SK, Sharma S. Tension pneumoventricle after excision of third ventricular tumor in sitting position. J Anaesthesiol Clin Pharmacol 2011;27(03):409-411

8 Monas J, Peak DA. Spontaneous tension pneumocephalus resulting from a scalp fistula in a patient with a remotely placed ventriculoperitoneal shunt. Ann Emerg Med 2010;56(04):378-381
9 Barbosa FT, Cunha RM, Rocha APC, Silva Júnior HJL. [Intraventricular pneumocephalus after accidental perforation of the dura mater: case report.]. Rev Bras Anestesiol 2006;56(05):511-517

10 Rao V, Fredriksli O, Gulati S. Post-traumatic epidural tension pneumocephalus: a case report.J Med Case Reports 2015;9(09):151

11 Paiva WS, de Andrade AF, Figueiredo EG, Amorim RL, Prudente $\mathrm{M}$, Teixeira MJ. Effects of hyperbaric oxygenation therapy on symptomatic pneumocephalus. Ther Clin Risk Manag 2014; 10:769-773 